\title{
Beliefs and Classroom Assessment Practices of English Teachers in Primary Schools in Thailand
}

\section{Arthitaya Narathakoon}

Chulalongkorn University, Bangkok, Thailand, arthitaya.n@litu.tu.ac.th

\section{Sutthirak Sapsirin}

Asst. Prof., Chulalongkorn University, Bangkok, Thailand, sutthirak.s@chula.ac.th

\section{Pramarn Subphadoongchone}

Ph.D., Chulalongkorn University, Bangkok, Thailand, pramarn.su@kmitl.ac.th

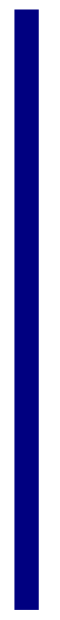

\begin{abstract}
The purpose of the present study is to investigate 1) the teachers' beliefs about classroom assessment in English, 2) their actual classroom practices, and 3) the extent to which their beliefs are congruent with their actual assessment practices. The participants were grade-6 English teachers in a school district from the northeastern part of Thailand. The present study was conducted using a mixmethods approach. The study consisted of two phases. Phase 1 involved the administration of a questionnaire to 97 teachers. Phase 2 was comprised of two parts: 2.1 classroom observation and stimulated recall with six teachers and 2.2 semi-structured interviews with 13 teachers. The findings revealed the teachers' beliefs about the use of classroom assessment and the classroom assessment methods. In addition, this study showed that the teachers' assessment practices were shifted from using various assessment methods to limited assessment methods due to the O-NET tutoring policy. Incongruence between the teachers' beliefs and practices could be influenced by the contextual factors such as educational policy, time constraints, excessive workload, and teacher's lack of assessment knowledge. The implications of the study were also provided.
\end{abstract}

Keywords: classroom assessment, teachers' beliefs, teachers' practices, Thai primary school teachers, English teachers

\section{INTRODUCTION}

In recent decades, there has been an increasing interest in teachers' beliefs. Beliefs are vital because they are considered as the strongest factors that can predict teaching behavior (Pajares, 1992). In classroom, beliefs play a great vital role in teachers' decision, judgment and behaviors (Borg , 2001) Moreover, they place an influence on

Citation: Narathakoon, A., Sapsirin, S., \& Subphadoongchone, P. (2020). Beliefs and Classroom Assessment Practices of English Teachers in Primary Schools in Thailand. International Journal of Instruction, 13(3), 137-156. https://doi.org/10.29333/iji.2020.13310a 
teachers' pedagogical decision-making (Borg 2003; Pajares 1992), the implication of new teaching approaches, techniques and activities ( $\mathrm{Li}, 2008)$, choice of subjects and classroom activities and evaluation in the classroom (Borg, 2001). In addition to the impact on instructional aspects, Adams and Hsu (1998) claim that teachers' beliefs of assessment "encompass a variety of assessment techniques, strategies, and tasks" (p. 178). In particular, beliefs put a strong effect on teachers' assessment practices (Borg, 2001; Burns , 1992; Lee , 2008; Pajares, 1992).

Despite potential problems of the mismatch between beliefs and practices, the issue has been under investigation. Borg (2009) argued that the studies of teachers' beliefs about adults and tertiary education have been found and available. On the contrary, the research in primary and secondary state school contexts where non-native speakers of English work with larger classes has been less explored. In particular to Thai contexts, few studies have paid attention to the relationship between teachers' belief and their actual practices in Thai context in particular primary teachers. Therefore, this study explored such relationship between teachers' beliefs and their actual practice of Thai primary teachers in terms of classroom assessment to see whether they were congruent or incongruent and to investigate what factors caused the incongruence between them.

\section{Language Policy in Thailand}

According to the National Education Act of 1999, learners' performance should be progressively assessed through observation. In addition, there was a shift in the teaching trend from grammar translation to communicative teaching (Punthumasen, 2007) and from teacher-centeredness to a learner-centered instruction (Prapaisit de Segovia \& Hardison, 2008) as stated in the National Educational Policy, English Language Institute, Office of the Basic Education Commission, 2008. The shift from assessment of learning to assessment for learning has also influenced the Thai education to keep up with the global trend (Prapaisit de Segovia \& Hardison, 2008). As a result of this, the reform has been put forward for Thai teachers to transform classroom assessment and moved away from teach-to-test classrooms. Its expectation is to advance students' language competency for more effective communication.

\section{Washback of National Tests}

In the Thai context, national tests can place a great impact on Thai education. Prapphal (2008) stated that "the washback effects of university entrance exams are clearly observable" (P.129). Since the university admission entrance examination, one of the high-stakes tests in Thailand mostly contains multiple choices format (Prapphal, 2008; Watson Todd, 2008), the negative washback occurs as a consequence of heavy use of this nonproductive skill in language assessment. According to Watson Todd (2008), there had been a change from the entrance exams to a newer version of national highstakes test called O-NET (Ordinary National Educational Test) in 2006. O-NET is a compulsory examination for students who graduate from Prathomsuka 6 (equivalent to grade 6), Mathayomsuksa 3 (equivalent to grade 9), and Mathayomsuksa 6 (equivalent to grade 12) must take prior to their graduation. Since then, it has been influencing the pedagogical and assessment perspectives of English teachers in Thailand. In addition, 
Nonthaisong (2015) pointed out that even though the English language policy in the Basic Education Core Curriculum B.E. 2551 (A.D. 2008) places an emphasis on communication, the O-NET focuses on discrete items, grammar, vocabulary, and reading comprehension, resulting in a clear discrepancy in goals. Research Objectives of the study

The objectives of the study are as follows:

1) To investigate English teachers' beliefs about classroom assessment

2) To investigate English teachers' actual classroom assessment practices

3) To examine the extent to which English teachers' stated beliefs are congruent with their actual classroom assessment practices

\section{REVIEW OF LITERATURE}

\section{Teachers' Beliefs}

In Borg's (2006) review of many studies in the field of teacher education, they confirm that many factors, including the teacher's school experience, professional education, and contextual factors could give an influence on teaching practices of both experienced and inexperienced teachers. According to Borg (2006), the research shows that experienced teachers' teaching and instruction depend on their constructed knowledge of teaching. For example, experienced teachers understand the lessons and know how to teach the lesson appropriately. With their comprehensive teaching experience, their beliefs about the classroom and the students are clear. On the contrary, novice teachers who lack this knowledge seem to receive an influence predominantly from contextual factors in schools and classrooms. Even though they are equipped with knowledge and principles from their previous teacher education, they can still alter their beliefs and principles during actual teaching practices because of many contextual factors such as large classes, the students' poor language performance, and pressures from examinations. Professional relationships among teachers and their worries over how to cope with students' learning may also adjust their teaching principles from what they have learned. Drawing on his review of a wide range of research studies of how teacher classroom practices are influenced by social, professional and personal factors, Borg (2006) proposed the model of teacher cognition which frames the analysis of factors influencing teacher beliefs driving their classroom assessment practices in this study. The Borg model is presented below. Teachers' classroom practices are influenced by teachers' beliefs driven by numerous factors including social, professional and personal factors. These influences are demonstrated by the Borg (2006) model of language teacher cognition in Figure 1 below. 


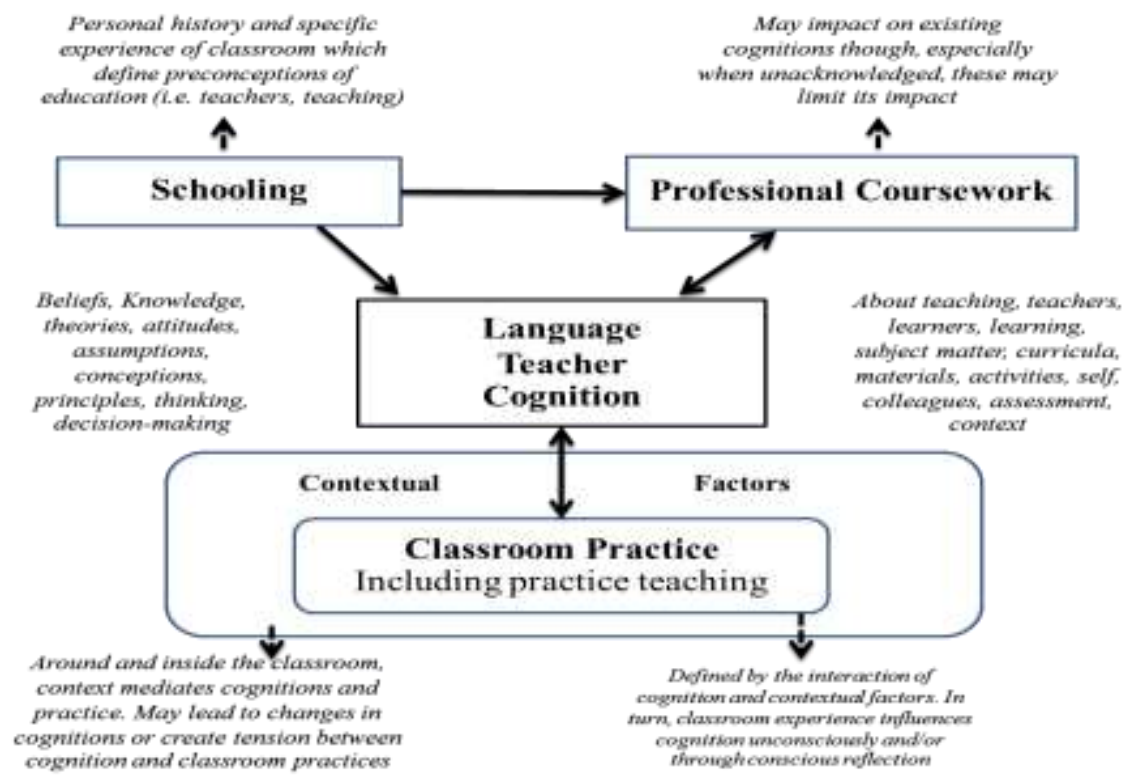

Figure 1

Elements and Processes in Language Teacher Cognition (Borg, 2006)

\section{Classroom Assessment Methods}

Assessment cannot occur without the tools. Regarding the language assessment, Katz and Gottlieb (2013) divide the types of language assessment into two broad categories: selected-response formats and constructed-response format. The framework ranges from teacher-made assessment to formal assessment such as observation and there are various types of assessment methods as shown in the table below.

Table 1

Types of Language Assessment (Katz \& Gottlieb, 2013)

\begin{tabular}{|c|c|c|c|c|}
\hline \multirow{4}{*}{$\begin{array}{l}\text { Selected response } \\
\text { Multiple choice } \\
\text { True/false } \\
\text { Matching } \\
\text { Same/different } \\
\text { Grammatical/ } \\
\text { ungrammatical }\end{array}$} & \multicolumn{4}{|c|}{ Constructed Response format } \\
\hline & Brief Constructed & \multicolumn{3}{|c|}{ Performance-Based Assessment } \\
\hline & $\begin{array}{l}\text { Gap fill } \\
\text { Short answer }\end{array}$ & Product-focused & $\begin{array}{l}\text { Performance- } \\
\text { focused }\end{array}$ & Process-focused \\
\hline & $\begin{array}{l}\text { Cloze } \\
\text { Label a visual } \\
\text { Sentence } \\
\text { completion }\end{array}$ & $\begin{array}{l}\text { Essay } \\
\text { Story/play/poem } \\
\text { Portfolio } \\
\text { Report } \\
\text { Video/audiotape } \\
\text { Poster session } \\
\text { Project }\end{array}$ & $\begin{array}{l}\text { Oral Presentation } \\
\text { Dramatic reading } \\
\text { Role-Play } \\
\text { Debate } \\
\text { Interview } \\
\text { Online chat }\end{array}$ & $\begin{array}{l}\text { Observation } \\
\text { Checklist } \\
\text { Rubric } \\
\text { Anecdotal notes } \\
\text { Reflection } \\
\text { Journal } \\
\text { Learning log }\end{array}$ \\
\hline
\end{tabular}

\section{Related studies on classroom assessment}

The studies of classroom assessment can be found in an array of subjects, not only in English. The focus of the research aims to investigate the teachers' practices in the 
actual classroom settings. Frey and Schmitt (2010) conducted a survey study with 140 teachers from various subjects including math, science, social studies and language arts starting from Grade 3 to Grade 12 in one US Midwestern state. Its focus was on the types of classroom assessment practices commonly used in their classes and the percentage of time they applied different types of classroom assessment. From this study, it can be summarized that traditional paper-and-pencil testing was still prevalent among teachers from different subjects, and testing frequently took place after instruction. All in all, the researchers indicated the reason underlying these phenomena involving the lack of training for teacher-made test, and during that time, large-scale test and score interpretation were predominant training.

In relation to assessment purposes and methods, Wicking (2017) explored the teachers' beliefs and practices in language assessment. The survey questionnaire was used to investigate 148 English teachers in Japanese universities. The study was aimed to look into three assessment beliefs including assessment purposes, assessment methods and assessment procedures. The results revealed that most common purpose of assessment was to determine students' final grades, followed by four student-centered purposes: to obtain students' progress, to provide feedback to students, to diagnose students' strengths and weaknesses, and to motivate students to work harder. Regarding the teaching purposes, their agreement on using assessment as a tool for teaching and teacher self-improvement purpose was not as strong as for student-focused purposes because they were still unsure about using assessment for their own professional development. Overall, these Japanese teachers held the beliefs that the purpose of assessment should aim towards the student-oriented principles and empower the learners' learning performance.

The recent case study about EFL teacher's classroom assessment practice indicated formative assessment and summative assessment work well together in a classroom assessment when the curriculum was well-designed, which pushed students to achieve their learning goal (Wang, 2017). The study was conducted with an EFL experienced teacher teaching public speaking course in a university in China. The data analysis showed that the teacher implemented a variety of classroom assessment practices throughout the whole semester and these can be divided into two categories: recognized assessment practices such as final test or task, and unrecognized formative assessment embedded in the instruction in class. This study revealed the high level of interaction between formative and summative practices. This was an example of the study whose participant was highly-experienced and had many years of teaching.

Recently, much research has been conducted to explore teachers' assessment practices in various countries. In Turkish school context, and Acar-Erdol and Yildizlı (2018) conducted the survey study with 288 teachers and observed 24 teachers in three levels: primary, secondary and high schools in a province. The study showed that teachers seemed to apply assessment of learning and placed an emphasis on the end product of the assessment. The inconsistency between teachers' beliefs and their classroom assessment was shown in this study from different factors. Regarding the factors that influences their practices, characteristics of students was considered to affect the 
teachers' practice the most, followed by curriculum, national examinations and technology.

\section{METHOD}

\section{Research Design}

In this study, the researcher implemented a mixed-methods research design in sequential data collection. This study consisted of two phases. In the first phase of the study, which dealt with the questionnaire survey, the researcher investigated teachers' beliefs and practices regarding classroom assessment by distributing the questionnaire to primary English teachers in the district. The second phase of the study embedded two sub-stages: 2.1 classroom observation and stimulated recall with six teachers from different schools in the same district and 2.2 an interview with 13 teachers using semi-structured interview.

\section{Research Instruments}

There were four research instruments adopted in this study, namely, questionnaire, interview, classroom observation and stimulated recall. The purpose of using all four methods was to allow the clarification and support of the relationship between teachers' beliefs and actual classroom assessment practices.

\section{Phase 1: Questionnaire}

The questionnaire was designed to explore the teachers' belief about classroom assessment practices and the purposes of classroom assessment.

\section{Phase 2.1: Observation and stimulated recall}

This phase of the study was carried out to receive in-depth information about teachers' classroom assessment practices and the reasons of their choices. The phase was designed to investigate the actual practices taken place in the natural classroom setting and to examine the underlying reason of each classroom assessment practice from the teachers. The observation and stimulated recall were sequentially ordered.

\section{Phase 2.2: Interview}

In this phase, the teachers were interviewed using two research instruments: a semistructured interview. This part was to extract deeper information about the teachers' beliefs, underlying their classroom assessment practices.

\section{Validation of the questionnaire and interview questions}

The content validity, structure, and bias of the questionnaire and interview questions were determined by three experts in the fields of language testing. The overall questionnaire, as validated by the experts, was approved with an acceptable IOC value (0.948).

\section{Context of the Study}

The study was conducted at one primary-school district in the northeastern part of Thailand. There were 107 schools. The number of English teachers in each school 
varied from one to three English teachers depending on the number of the students. Most of these English teachers in this school district graduated with Basic Education major while some did not hold any English-related bachelor's degree. The number of students ranged from 4 to 40 students per class depending on the size of the school. Due to teacher shortage in those schools, one teacher might be responsible for more than one subject. For example, some teachers taught two subjects: Physical Education and English while some were given all the subjects taught in Grade 6.

According to the Office of Basic Education Commission (OBEC), in one academic year students are required to study 80 hours of English class: 40 hours in the first semester and another 40 hours in the second semester. The first semester starts from the mid of May to September and the second semester starts from the first week of November to March. In each week, there are two 1-hour classes and the total adds up to 2 hours a week for 20 weeks.

This study was conducted during the second semester, which was composed of 20 weeks starting from November to March. In regard to the examination, the midterm examination was held in the middle of January and the final examination took place in the second week of March. In addition to these two examinations, the Ordinary National Education Test (O-Net) was scheduled for all grade 6 students during the first week of February.

\section{Participants of the study}

The population of this study was a group of Thai EFL teachers who were teaching English in primary schools in the same school district.

\section{Respondents in Questionnaire}

The respondents in this phase were selected using a purposive sampling method. There were 112 teachers during the time the study was conducted. The researcher distributed the questionnaire to all primary teachers who taught English in Grade 6. None of them were taken out from the data analysis.

\section{Participants in Phase 2}

The techniques to select the interview informants in this phase were voluntary sampling and snowballing. Of 112 English teachers in a school district, 6 participants were selected for this phase of the study. These six participants were also recruited in Phase 2.2 in order that the data can be triangulated. The participants in this phase were selected using purposive sampling with theory or concept sampling. All these six teachers participated on a voluntary basis as well. The selection criteria for the participants in this phase of the study included the following: different years of teaching, different educational degrees, different numbers of the students in class and different ages. 
Table 2

Participants of the Study in Phase 2.1 and 2.2

\begin{tabular}{|c|c|c|c|c|c|c|c|}
\hline \multicolumn{4}{|c|}{ Personal information } & \multicolumn{2}{|c|}{ Experience } & \multicolumn{2}{|l|}{ School context } \\
\hline Name & Gender & Age & Degree & $\begin{array}{l}\text { Years of } \\
\text { teaching } \\
\text { English }\end{array}$ & $\begin{array}{l}\text { Studied } \\
\text { /Training in } \\
\text { assessment }\end{array}$ & Subjects taught & $\begin{array}{l}\text { No. of } \\
\text { students } \\
\text { in class }\end{array}$ \\
\hline$\overline{\mathrm{K}} 1$ & Female & 58 & $\begin{array}{l}\text { B. Ed. (major: Home } \\
\text { economics/ minor: English) } \\
\text { M. Ed. (Curriculum and } \\
\text { Instruction) }\end{array}$ & 20 & yes & $\begin{array}{l}\text { English, Thai, Home } \\
\text { economics }\end{array}$ & 17 \\
\hline $\mathrm{K} 2$ & Female & 35 & $\begin{array}{l}\text { B.A. in English } \\
\text { M.A. in TESOL }\end{array}$ & 11 & yes & English, Math & 30 \\
\hline $\mathrm{K} 3$ & Female & 40 & $\begin{array}{l}\text { B.A. in English } \\
\text { M.A. in TESOL }\end{array}$ & 13 & yes & $\begin{array}{l}\text { English, Art, PE, } \\
\text { Home Economics } \\
\text { and Technology, } \\
\text { History, Citizenship }\end{array}$ & 32 \\
\hline $\mathrm{K} 4$ & Female & 28 & B.A. in English & 2 & yes & $\begin{array}{l}\text { English, Art, PE, } \\
\text { ASEAN Studies, } \\
\text { Health }\end{array}$ & 17 \\
\hline K5 & Female & 47 & $\begin{array}{l}\text { B.Ed. (major in English) } \\
\text { M.A. in TESOL }\end{array}$ & 18 & no & $\begin{array}{l}\text { English, } \\
\text { Boy Scout }\end{array}$ & 30 \\
\hline K6 & Female & 46 & $\begin{array}{l}\text { B.Ed. (major: primary } \\
\text { education) } \\
\text { M.A. in English }\end{array}$ & 23 & yes & $\begin{array}{l}\text { English, } \\
\text { Boy Scout }\end{array}$ & 20 \\
\hline K7 & Female & 41 & $\begin{array}{l}\text { B.Ed. in English } \\
\text { M.Ed. in Educational } \\
\text { Administration }\end{array}$ & 12 & no & $\begin{array}{l}\text { English, Social } \\
\text { Science, Arts, } \\
\text { History }\end{array}$ & 22 \\
\hline K8 & Female & 40 & $\begin{array}{l}\text { B.A. in English } \\
\text { M.A. in TESOL }\end{array}$ & 11 & yes & $\begin{array}{l}\text { English, } \\
\text { Boy Scout }\end{array}$ & 23 \\
\hline K9 & Female & 51 & $\begin{array}{l}\text { B.A. in English } \\
\text { M.A. in Teaching English }\end{array}$ & 27 & yes & $\begin{array}{l}\text { English, } \\
\text { Boy Scout }\end{array}$ & 40 \\
\hline$\overline{\mathrm{K}} 10$ & Female & 35 & $\begin{array}{l}\text { B.A. in English } \\
\text { M.A. in TESOL }\end{array}$ & 11 & yes & English, Art & 12 \\
\hline K11 & Female & 33 & $\begin{array}{l}\text { B.Ed. (major in English) } \\
\text { M.Ed. in Educational } \\
\text { Administration }\end{array}$ & 7 & yes & English & 22 \\
\hline $\mathrm{K} 12$ & Female & 46 & $\begin{array}{l}\text { B.Ed. in Psychology - } \\
\text { Mathematics (minor in } \\
\text { science) } \\
\text { M. Ed. in Educational } \\
\text { Research and Evaluation }\end{array}$ & 11 & yes & $\begin{array}{l}\text { English, PE, Math, } \\
\text { Social, Thai, Boy } \\
\text { Scout, }\end{array}$ & 14 \\
\hline K13 & Male & 56 & $\begin{array}{l}\text { B.Ed. (major: Thai/ minor: } \\
\text { Psychology) } \\
\text { M.Ed. in Educational } \\
\text { Administration }\end{array}$ & 20 & no & $\begin{array}{l}\text { English, PE, Art, } \\
\text { Science, Thai, Math, } \\
\text { Social Science, } \\
\text { Boy Scout, Home } \\
\text { Economics }\end{array}$ & 8 \\
\hline
\end{tabular}

\section{Data Collection}

The data collection process started in November 2016 and finished in March 2017. It was carried out during the second semester of Academic Year 2016.

\section{Data Analysis}

For quantitative data, the questionnaire was quantitatively analyzed using descriptive statistics. In addition, the items in the open-ended part were processed by means of the content analysis. For qualitative data, there were three research instruments including semi-structured interview, classroom observation and stimulated recalls. All verbal data were transcribed and the transcriptions in Thai were used in the data analysis. Only the 
quotes that were extracted to use in the report were translated into Thai. The verbal data were typed into Microsoft Word and then transferred to NVivo12 software. This software allowed the coded segments to be easily checked across all scripts. The intercoder agreement was used to ensure reliability in the coding scheme. Another coder, the university teacher and also the expert in the qualitative research, was contacted and asked to code two sets of each verbal data set independently, based on the coding scheme. If there were any disagreement, we discussed to reach the final consensus.

\section{FINDINGS}

The sources of data were drawn from the questionnaire and interviews. The second part reports on the teachers' actual classroom assessment practices. Observation and stimulated recalls served as the data source.

Table 3

Demographic Information of Questionnaire Respondents

\begin{tabular}{lll}
\hline \multicolumn{2}{l}{ Frequency } & Percent \\
\hline Gender & 76 & 78.35 \\
\hline Female & 21 & 21.65 \\
\hline Male & 3 & \\
\hline Education & 39 & 3.09 \\
\hline Ph.D. & 55 (20 non-English majors, & 40.21 \\
\hline Master's degree & 35 English-related majors) & \\
\hline Bachelor's degree & 35.70 \\
& 62 & \\
\hline Studied any assessment courses & 36.08 \\
\hline Yes & 63.92 \\
\hline No & 21 & \\
\hline Attended any conference about assessment & 21.65 \\
\hline Yes & 76 & 78.35 \\
\hline No & 15 & 15.46 \\
\hline Attended any training in assessment & 84.54 \\
\hline Yes & 82 & \\
\hline No & & \\
\hline
\end{tabular}

\section{Demographic information}

The majority of the respondents were female teachers (76), while only 21 teachers were males. With regard to their educational qualifications, only 3 teachers in this school district possess a doctoral degree ( 2 in Psychology and 1 in Educational Administration). 39 teachers hold a master degree from various majors naming Educational Administration, Teaching English as a Second Language, Teaching English as a Foreign Language, and Curriculum and Teaching. Most of the teachers (55) obtained at least a Bachelor's degree from a wider variety of majors. Of 55 teachers, 35 teachers graduated from English-related majors, while 22 graduated from other majors including Psychology, Thai, Science, Mathematics, Economics, and Arts. In addition, $63 \%, 78 \%$ and $84 \%$ of the respondents never studied any assessment courses or attended any conference or training in language assessment respectively. 
Table 4

Average Numbers of Years and Hours of Teaching

\begin{tabular}{ll}
\hline & Average \\
\hline Years of teaching & 8.8 years \\
\hline Hours of teaching English per week & 12 hours \\
\hline House of teaching other subjects per week & 12 hours \\
\hline
\end{tabular}

From the table, the average year of teaching of the teachers in this school district was 8.8 years. The average numbers of hours of teaching English and other subjects were 12 hours.

Table 5

The Grades Teachers were Responsible to Teach

\begin{tabular}{lll}
\hline Grades & $\mathrm{N}$ & Percent \\
\hline Grade 1 & 33 & 34.02 \\
\hline Grade 2 & 35 & 36.08 \\
\hline Grade 3 & 36 & 37.11 \\
\hline Grade 4 & 65 & 67.11 \\
\hline Grade 5 & 72 & 74.23 \\
\hline Grade 6 & 97 & 100 \\
\hline Grade 7 & 25 & 25.77 \\
\hline Grade 8 & 21 & 21.65 \\
\hline Grade 9 & 22 & 22.68 \\
\hline
\end{tabular}

As shown in the table, although there were 97 teachers answering the questionnaire, the numbers indicated that one teacher was assigned to teach more than one grade. That is, when looking closely at Grade 4, Grade 5 and Grade 6, teachers who were assigned to teach grade 6 , most of the time they also taught Grade 4 and Grade 5 as well. However, to participate, all of the participants in this study taught English in Grade 6 during the time this study was conducted.

Table 6

Other Subjects the Teachers Taught in One Semester

\begin{tabular}{lll}
\hline Teaching subjects & $\mathrm{n}$ & $\%$ \\
\hline Arts & 47 & 48.45 \\
\hline Social science & 38 & 39.18 \\
\hline Science & 33 & 34.02 \\
\hline Thai & 43 & 44.33 \\
\hline Physical Education & 35 & 36.08 \\
\hline Mathematics & 39 & 40.21 \\
\hline Other subjects* & 54 & 55.67
\end{tabular}

*Others including Boy Scout, ASEAN Study, Computer, Thai Classical Dance, Citizenship, History, Health and Hygiene, Home Economics, and Guidance

It can be seen that in addition to teaching English, some teachers were responsible to teach other subjects as well. 


\section{Teachers' Beliefs about classroom assessment methods and formats Results from the questionnaire}

In this part of the questionnaire, the teachers were asked to indicate their beliefs on classroom assessment methods and formats. The interpretations of teachers' beliefs about how classroom assessment methods can assess their students' English proficiency shown below.

$\begin{array}{ll}\text { Very low } & 1.00-1.49 \\ \text { Low } & 1.50-2.49 \\ \text { Moderate } & 2.50-3.49 \\ \text { High } & 3.50-4.49 \\ \text { Very high } & 4.50-5.00\end{array}$

Table 7

Teachers' Beliefs on the Extent to which these Classroom Assessment Methods and Formats Can Assess Their Students' English Proficiency

\begin{tabular}{|c|c|c|c|}
\hline Classroom assessment methods & Mean & SD & Level of belief \\
\hline Asking Questions & 3.87 & 0.89 & High \\
\hline Homework & 3.34 & 0.92 & Moderate \\
\hline Dictation & 3.76 & 0.93 & High \\
\hline Individual Work & 3.73 & 0.93 & High \\
\hline Pair Work & 3.57 & 0.78 & High \\
\hline Group Work & 3.34 & 0.93 & Moderate \\
\hline Student Self-Assessment & 3.19 & 0.93 & Moderate \\
\hline Peer Assessment & 3.22 & 0.84 & Moderate \\
\hline Play & 3.38 & 0.99 & Moderate \\
\hline Portfolio & 3.46 & 0.83 & Moderate \\
\hline Poster & 3.13 & 0.79 & Moderate \\
\hline Project & 3.51 & 1.08 & High \\
\hline Oral Presentation & 3.80 & 0.94 & High \\
\hline Role Play & 3.75 & 0.96 & High \\
\hline Interview & 3.70 & 0.86 & High \\
\hline Dramatic Reading & 3.07 & 0.95 & Moderate \\
\hline Student Observation & 3.76 & 0.91 & High \\
\hline Journal & 3.54 & 0.98 & High \\
\hline Learning $\log$ & 3.59 & 0.95 & High \\
\hline Quizzes & 3.89 & 0.76 & High \\
\hline Midterm test & 3.84 & 0.84 & High \\
\hline Final & 3.92 & 0.80 & High \\
\hline Classroom assessment format & Mean & SD & Level of belief \\
\hline Multiple choice & 3.46 & 0.99 & Moderate \\
\hline True/false & 3.42 & 0.88 & Moderate \\
\hline Matching & 3.52 & 0.83 & High \\
\hline Gap fill & 3.87 & 0.85 & High \\
\hline Short answer & 3.82 & 0.85 & High \\
\hline Label a diagram & 3.63 & 1.10 & High \\
\hline Sentence completion & 3.93 & 0.97 & High \\
\hline
\end{tabular}

From Table 7, among 14 classroom assessment methods which were rated at a high level, the top three methods were final assessment, quizzes and asking questions (3.93, 3.89 and 3.87, respectively). Among 8 methods rated at a moderate level, the top three 
were play, homework and group work (3.38, 3.34 and 3.34 respectively). Of all the methods, three methods that received the lowest rating were self-assessment, poster and dramatic reading $(3.19,3.13$ and 3.07 respectively).

In terms of classroom assessment formats, it appears that the respondents highly believed that sentence completion can be used to check students' English proficiency, while other formats namely multiple choices and true/false format were also believed to be used to assess their students in class.

\section{Teachers' Practices about classroom assessment methods and formats Results from the questionnaire}

In this part, the respondents rated their classroom assessment practices on different frequencies. With regard to their frequency on classroom assessment practices, their responses revealed three different levels of practices - rarely, sometimes and often.

The frequencies of teachers' use in classroom assessment are indicated below.

$\begin{array}{ll}\text { Never } & 1.00-1.49 \\ \text { Rarely } & 1.50-2.49 \\ \text { Sometimes } & 2.50-3.49 \\ \text { Often } & 3.50-4.49 \\ \text { Always } & 4.50-5.00\end{array}$

Table 8

The Frequency of the Teachers' use of these Classroom Assessment Methods and Pattern in Their Class

\begin{tabular}{llll}
\hline Classroom assessment methods & Mean & SD & Frequency \\
\hline Asking Questions & 4.04 & 0.78 & Often \\
\hline Homework & 3.87 & 0.87 & Often \\
\hline Dictation & 3.37 & 0.88 & Sometimes \\
\hline Individual Work & 3.99 & 0.77 & Often \\
\hline Pair Work & 3.73 & 0.72 & Often \\
\hline Group Work & 3.24 & 0.80 & Sometimes \\
\hline Student Self-Assessment & 2.71 & 0.97 & Sometimes \\
\hline Peer Assessment & 2.47 & 0.82 & rarely \\
\hline Play & 2.16 & 0.98 & rarely \\
\hline Portfolio & 3.27 & 1.04 & Sometimes \\
\hline Poster & 2.34 & 0.93 & rarely \\
\hline Project & 2.10 & 1.00 & rarely \\
\hline Oral Presentation & 2.84 & 0.99 & Sometimes \\
\hline Role Play & 2.76 & 0.93 & Sometimes \\
\hline Interview & 2.68 & 0.88 & Sometimes \\
\hline Dramatic Reading & 2.10 & 0.99 & rarely \\
\hline Student Observation & 4.18 & 0.85 & Often \\
\hline Journal & 2.78 & 1.17 & Sometimes \\
\hline Learning log & 2.75 & 1.13 & Sometimes \\
\hline Quizzes & 3.99 & 0.68 & Often \\
\hline Midterm test & 4.29 & 0.82 & Often \\
\hline Final & 4.29 & 0.88 & Often \\
\hline Classroom assessment formats & Mean & SD & Frequency \\
\hline Multiple choice & 3.93 & 0.97 & Often \\
\hline
\end{tabular}




\begin{tabular}{llll}
\hline True/false & 3.87 & 0.85 & Often \\
\hline Gap fill & 3.82 & 0.85 & Often \\
\hline Matching & 3.63 & 1.10 & Often \\
\hline Short answer & 3.52 & 0.83 & Often \\
\hline Label a diagram & 3.46 & 0.99 & Sometimes \\
\hline Sentence completion & 3.42 & 0.88 & Sometimes \\
\hline
\end{tabular}

From the table, it can be seen that the most frequent classroom assessment practices were midterm examination, final examination, and student observation $(4.29,4.29$ and 4.18 respectively). Dramatic reading and project were the two least frequent classroom assessment methods, which were rated as rare use (2.10). The classroom assessment format the teachers use the most frequent was multiple choices, which was rated at 3.93 (often). On the other hand, the least frequently used format was sentence completion, which was rated "sometimes".

\section{Findings from classroom observation and stimulated recalls}

The following are the summary of the classroom assessment practices each teacher in the study chose to assess their students in each class.

Table 9

Summary of Classroom Assessment Practices during the Classroom Observation

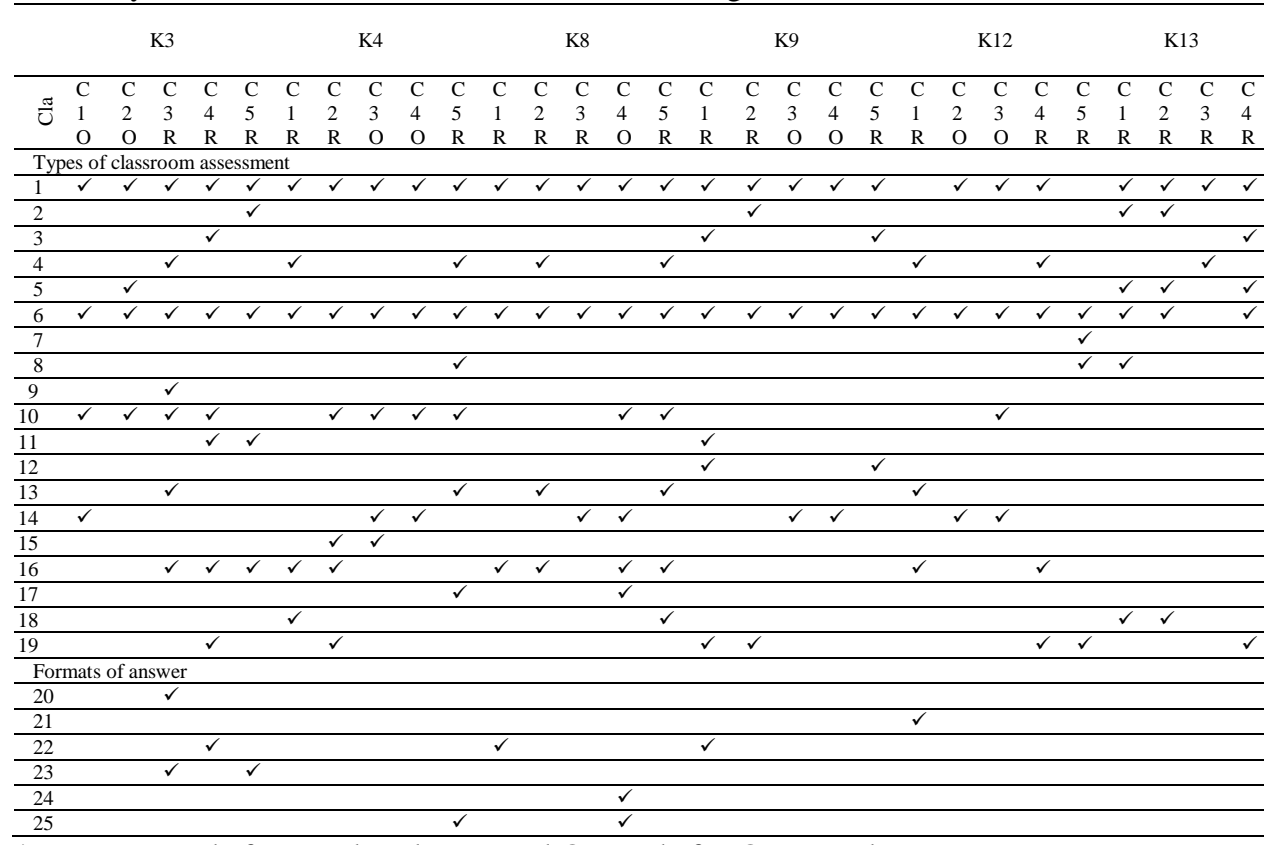

*Note: $\mathrm{R}$ stands for regular classes and $\mathrm{O}$ stands for O-NET classes.

Numbers stand for classroom assessment methods: $1=$ asking questions, $2=$ dictation, $3=$ games, 4=homework, $5=$ dialogue, $6=$ observation, $7=$ poster, $8=$ presentation, $9=$ quizzes, $10=$ read aloud, $11=$ rearrange sentences, $12=$ role play, $13=$ sentence writing, $14=$ past $\mathrm{O}-\mathrm{NET}$ test, $15=$ 
translation, $16=$ worksheet, $17=$ individual, $18=$ pair work, $19=$ group work, $20=$ multiple choices, $21=$ true/false, 22=matching, 23=gap filling, 24= label diagram, 25= sentence completion

The findings from classroom observation and stimulated recalls showed that the teachers implemented various classroom assessment methods in the regular classes. Their results from the observation and stimulated recall revealed that their assessment practices mostly included asking questions, observation, read aloud, and worksheet in their classroom. These four practices were used by all the teachers in this study. From the observation, the teachers continuously observed their students while they were on tasks and asked their students questions for various reasons. The teachers' classroom assessment consisted of wider choices such as role play, games, group work or translation. Similar to the data from the questionnaire, presentation and poster were rarely found; they were used only once by K12. The use of play, project, peer assessment and student self-assessment to assess students was not seen in any of the classes in this study.

Unlike the regular classes, assessment practices in O-NET tutoring classes were dramatically different from those in regular classes. That is, during the tutoring classes, classroom assessment methods were limited to asking questions, observation, using past O-NET test and read aloud. Most of the class hours were spent on practicing students' test taking skills on past O-NET examination papers.

\section{DISCUSSION}

This part discusses the factors which might shape the teachers' beliefs and cause teachers' incongruence between their beliefs and classroom assessment practices.

\section{Factors Shaping the Teachers' Beliefs}

There could be several factors that shape the beliefs of the teachers in this study. In this study, the result of this study showed that schooling, teachers' training and informal collaboration should be factors which shaped the teachers' beliefs.

\section{Schooling}

In this study, since most teachers in this study graduated with a degree in English or a degree in education, it can be surmised that their beliefs could be influenced by their schooling. During their educational courses, the teacher curriculum included assessment and testing as one of the subjects for the teachers so that they had been taught how to assess the students. This concurs with the finding of Yao (2015) that teacher education plays an important role in teachers' beliefs and understanding about classroom assessment.

\section{Teacher training}

Teacher training can also be one of the strong influences on teachers' beliefs. Some teachers in this study had attended the training in relation to assessment. For instance, some teachers participated in the training on how to use play, so this could shape their beliefs in using play as one of the classroom assessment methods. Moreover, one-year 
practicum could also shape teachers' beliefs in this study. One teacher in this study was doing her practicum for one year, which shaped her classroom assessment beliefs.

In this study, the teachers' beliefs in classroom assessment as shown in the findings above might be influenced by their education background as stated by Borg (2009). All of the teachers graduated with a degree in education and some received training in relation to assessment. Moreover, all teachers did practicum during their education. All of these may shape their beliefs about what methods can be used in classroom assessment.

\section{Informal collaboration}

In addition to educational background and training, informal collaboration among the teachers in the same school district seems to place a great role in shaping the teachers' beliefs. In the school district where the teachers in the present study worked, they shared and learnt from their peers in their own schools or from different schools with the help of today technology. During the observation, it can be seen that the teachers used Line or Facebook, which is an application or online community. This can connect the teachers in the community which enables them to share their knowledge with their peer teachers. This appears to be one of the communications which later can help the teachers in shaping their beliefs. This parallels Richards et al's (2001) findings which showed that working collaboratively with peers can promote positive changes in beliefs.

\section{Contextual Factors}

Contextual factors can place a great influence on teachers' practices. Contextual factors found in this study include educational policy, time constraint (Acar-Erdol \&Yildizli, 2008; Chan, 2008), excessive workload (Chan, 2008), and teachers' lack of assessment knowledge (Vandeyar \& Killen, 2007).

\section{Educational policy}

The reasons that could explain the teachers' behavior in the present study could be the pressure from the educational policy. According to the Basic Core Curriculum B.E. 2551, the Ministry of Education set out a national assessment policy that,

"Evaluation is conducted in order to assess learners' quality at national level, based on the learning standards prescribed in the Basic Education Core Curriculum. Educational institutions are required to arrange for assessment of all students in Grades 3, 6, 9 and 12." (p.33)

This part of the policy markedly explains that all schools in Thailand are obligated to administer a national test for their students in those four grades. As a result, it could put a heavy pressure on both schools and teachers in order to prepare their students for this mandatory examination. Specifically in this school district, the teachers received the letter issued from the authority and mandated all the schools and teachers to arrange the tutoring sessions, which had replaced the whole regular classes. 
As a consequence of the policy pressure, the teachers may want to ensure that their students could perform well in O-NET and their students' scores could be above the national average. The result offered a vital evidence for the influence of the national test on teachers' practices and also underlined the gap between the assessment policy and the actual teachers' practices in class. This supported the findings from Fitzpatrick (2011) in that the national test placed a pressure on teachers' practices.

In addition to the pressure, another factor is the results from O-NET which are used as a reward and promotion for the teachers and schools whose students' performance is ranked at the top levels. As seen in the excerpt from K10, she reported that the O-NET result could affect the teachers and schools because "the teachers whose students performed well in O-NET were honored as good teachers and the school would receive a compliment and reward." On the other hand, this O-NET score could be used as a punishment for both schools and teachers if the students in that school cannot perform well in the test.

The findings show that classroom assessment methods can be served as the preparation of high-stake test. Most teachers used the past O-NET test as classroom assessment method so they could prepare their students for this high-stakes test. The finding supported the result from the studies of Delandshere and Jones (1999), and Fitzpatrick (2011) in that assessment was implemented to prepare the students for mandated test or high-stakes test, suggesting that the teachers are likely to change their classroom assessment to the teach-to-test if they want to prepare their students for the test. This study showed the national high-stakes test influenced the teachers' practices in classroom. The teachers' practices were changed to teach-to-test when the high-stakes test became the focal point of their classes. As a result, classroom assessment methods can be served as the preparation of high-stake test.

\section{Time constraint}

All of the teachers in this study corroborated that a limitation of time can cause the teachers' problems in practicing classroom assessment since there are only two hours a week for English class in elementary school levels. Accordingly, this poses a challenge for the teachers to complete each class as planned and to assess their students after class. In the interview, K8 reported that time constraint was her most important problem as illustrated here:

"Time is very problematic since I have limited time in class. I have only 2 hours a week. Teaching and instructional activities takes up class time so there is not enough time for any assessment at all. I can't find the time to assess my students."

Another explanation from K3 was that she wanted to use play to assess her students in her class. However, with the limitation of time, she could not apply this method even though she mentioned that she had a belief in using this as one of her classroom assessment practices in the interview. As shown in the illustration, she said, 
"I wanted to use play to assess my students' performance. Unfortunately, I could not use this method since I only had an hour in each class. How could I manage this in an hour?"

\section{Excessive workloads}

In addition, teachers' other duties pose a challenge for the teachers to complete their classroom assessment. The majority of the teachers in this study reported that other school responsibilities took up their class hours and kept the teachers away from the class; consequently, the teachers could not spend their time conducting and assessing their students as scheduled. The excessive school responsibilities pushed the teachers away from their class and the teachers would not be able to assess their students' performance after class. In addition, the teachers revealed that they would rather choose worksheets as their choice of classroom assessment. They reasoned that they could finish up other school works while monitoring their students working on their worksheets.

\section{Teachers' lack of assessment knowledge}

Teachers' lack of assessment knowledge is a vital problem for a teacher who did not graduate with any English-related majors or never attended any assessment trainings or conferences as seen in K13. K13 who did not graduate from English major, expressed his concern about his lack of assessment knowledge. He raised his concern that

"I do not have enough knowledge to assess students' reading or to know writing and listening assessment. I do not have any confidence in assessing my students or writing some quizzes in class."

Even though K13 wanted to use role play to assess his students in the interview, he faced the difficulty in using them in class. This caused him to only assess his students with dialogue instead as seen in the classroom observation. He stated that he did not have enough confidence when assessing his students' proficiency in class. He was using the same assessment methods in most of his observed classes. It is quite evident that inconsistency between his beliefs and actual practice was a result from his lack of assessment knowledge.

Regarding teacher training, the findings reveal that professional training matters in both teachers' beliefs and classroom assessment practices. The findings show that having no training in assessment can have a negative impact on the assessment practices. Some teachers in this study concerned about their assessment knowledge. They felt that the trainings they had attended previously did not give them sufficient knowledge on classroom assessment for their daily classroom practices. In addition, even though they received some previous training, they did not feel that the assessment training equipped them with the capacity to assess their students. They had a difficulty to put what they learned in assessment courses into their actual practices.

This result echoed in many studies (e.g. Acar-Erdol \& Y1ldılı, 2018; Hussain et al, 2019; Muñoz et al, 2012, and Vandeyer \& Killen, 2007). These studies found that the teachers faced a difficulty in transferring their beliefs to the real classroom since some 
of the teachers reported lack of assessment knowledge, so they could not assess their students in class. In order to bridge the gap between their beliefs and practices and to assist the teachers in facing the challenges, the training should be provided for this group of teachers.

\section{IMPLICATIONS}

The findings from this study suggest several implications including assessment policy, educational programs, training programs and test formats regarding language assessment for young learners.

First, the assessment policy in core curriculum should be accessible, understandable and practical. To ensure that the policy is mutually and comprehensively understood by the teachers, policy makers should seek a more suitable way to inform the teachers of the assessment policy. The Office of the Basic Education Commission should work collaboratively with other stakeholders such as school principals, school supervisors, or teachers in designing curriculum and training. In addition, clear assessment guidelines in practicing classroom assessment should be provided for the teachers. However, the guidelines without any training support would not be able to assist the teachers to perform their full potential in class. The teachers should be properly informed of and effectively trained in classroom assessment methods specified in the policy.

Second, teacher educators in the Faculty of Education may consider redesigning assessment courses in the curriculum for both pre-service and in-service teachers with the possibilities of increasing the amount of credit hours that students spend on language assessment related courses. In particular, the teachers in this study taught grade 6 students who are considered to be young learners. Therefore, preparing teachers' knowledge on assessing English for this particular group of students is crucial since ways in which young learners are assessed is different from those used to assess adult learners (McKay, 2006). To design the curriculum for future teachers, the provision of the teacher education programs should be specially designed for testing and assessing English to young language learners. The curriculum in the undergraduate levels should have a program focusing on the pre-service teachers to understand the nature of assessing young learners.

Third, in-service teachers should be encouraged to participate in continuing professional development (CPD) focusing on classroom assessment training for young learners as well. In addition, the teachers should be equipped with both theoretical and practical knowledge, especially on formative assessment. To enhance teachers' continuing professional development, more hands-on and practical workshops should be provided for the teachers so that the teachers can apply the practical knowledge to their classes. Additionally, to assist in-service teachers whose degrees are not related to English teaching or the teachers who have heavy workload which may impede their participation of professional development programs, the classroom assessment manual with ready-touse classroom assessment materials for English would be useful and reduce the gap between experienced and inexperienced teachers. To increase the practicality of the 
manual, the workshop on how to use this manual should be organized to prepare the teachers.

Last, to act in accordance with the assessment policy in the core curriculum, the format of the test in the national test should be adjusted and cover all four skills. The national test, moreover, should not contain only discrete and traditional multiple- choice tests. It should follow the educational policy from the Office of the Basic Education Commission, Ministry of Education, which promotes both performance and alternative assessment so that this could reflect the assessment policy that has been initially set.

\section{REFERENCES}

Acar-Erdol, T., \& Yildizlı, H. (2018). Classroom assessment practices of teachers in Turkey. International Journal of Instruction, 11(3), 587-602. doi:https://doi.org/10.12973/iji.2018.11340a.

Adams, T. L., \& Hsu, J.-W. Y. (1998). Classroom assessment: Teachers' conceptions and practices in mathematics. School Science and Mathematics, 98(4), 174-180. doi:10.1111/j.1949-8594.1998.tb17413.x.

Borg, M. (2001). Key concepts in ELT. Teachers' beliefs. ELT Journal, 55(2), 186-188.

Borg, S. (2003). Teacher cognition in language teaching: A review of research on what language teachers think, know, believe, and do. Language teaching, 36(2), 81-109.

Borg, S. (2006). Teacher cognition and language education: Research and practice. London: Continuum.

Borg, S. (2009). Language teacher cognition. In A. R. Burns (Ed.), The Cambridge guide to second language teacher education (pp. 163-171). Cambridge: Cambridge U.

Burns, A. (1992). Teacher beliefs and their influence on classroom practice. Prospect, 7(3), 56-66.

Chan, Y.-C. (2008). Elementary school EFL teachers' beliefs and practices of multiple assessments. Reflections on English Language Teaching, 7(1), 37-62.

Delandshere, G., \& Jones, J. H. (1999). Elementary teachers' beliefs about assessment in mathematics: A case of assessment paralysis. Journal of Curriculum and Supervision, 14(3), 216.

Fitzpatrick, D. (2011). Making sense of the English language policy in Thailand: An exploration of teachers' practices and dispositions (Unpublished doctoral dissertation). The University of Exeter UK.

Frey, B. B., \& Schmitt, V. L. (2010). Teachers' classroom assessment practices. Middle Grades Research Journal, 5(3), 107-117.

Hussain, S., Shaheen, N., Ahmad, N., \& Islam, S. U. (2019). Teachers' classroom assessment practices: challenges and opportunities to classroom teachers in Pakistan. Dialogue, 14(1), 88-97. 
Katz, A., \& Gottlieb, M. (2013). Assessment in the classroom. In C.Chapelle (Ed.), The encyclopedia of applied linguistics. Singapore: Blackwell.

Lee, I. (2008). Ten mismatches between teachers' beliefs and written feedback practice. ELT Journal, 63(1), 13-22.

McKay, P. (2006). Assessing young language learners. Cambridge: Cambridge University Press.

Muñoz, A. P., Palacio, M., \& Escobar, L. (2012). Teachers' beliefs about assessment in an EFL context in Colombia. Profile Issues in TeachersProfessional Development, 14(1), 143-158.

Nonthaisong, K. (2015). The impact of the English language policy in the basic education core curriculum BE 2551 (AD 2008) on English instruction of Thai secondary EFL teachers: a multiple case study in northeast Thailand. University of Alabama Libraries,

Pajares, M. F. (1992). Teachers' beliefs and educational research: Cleaning up a messy construct. Review of Educational Research, 62, 307-332.

Prapaisit de Segovia, L., \& Hardison, D. M. (2008). Implementing education reform: EFL teachers' perspectives. ELT Journal, 63(2), 154-162.

Prapphal, K. (2008). Issues and trends in language testing and assessment in Thailand. Language Testing, 25(1), 127-143.

Punthumasen, P. (2007). International program for teacher education: An approach to tackling problems of English education in Thailand. Paper presented at the The 11th UNESCO-APEID International Conference Reinventing Higher Education: Toward Participatory and Sustainable Development.

Richards, J. C., Gallo, P. B., \& Renandya, W. A. (2001). Exploring teachers' beliefs and the processes of change. PAC journal, 1(1), 41-58.

Vandeyar, S., \& Killen, R. (2007). Educators' conceptions and practice of classroom assessments in post-apartheid South Africa. South African J of Edu, 27(1), 101-115.

Wang, X. (2017). A Chinese EFL Teacher's classroom assessment practices (Vol. 14).

Wicking, P. (2017). The assessment beliefs and practices of English teachers in Japanese Universities. JLTA Journal, 20, 76-89.

Yao, Y. (2015). Teacher perceptions of classroom assessment: A focus group interview. SRATE Journal, 24(2), 51-58. 